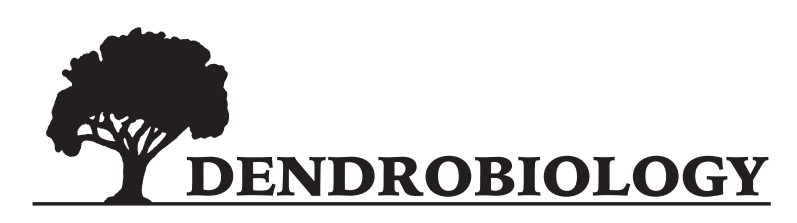

2014, vol. 72, 125-137

http://dx.doi.org/10.12657/denbio.072.011

\author{
Wojciech Szewczyk, Hanna Kwaśna*, Jan Bocianowski, \\ Jolanta Behnke-Borowczyk, Anna Ratajczak, Arleta Świetlik
}

\title{
Diversity of Armillaria ostoyae in Scots pine plantations in Poland
}

Received: 11 September 2013; Accepted: 20 May 2014

\begin{abstract}
Incidence of Armillaria root disease and the population structure of associated Armillaria spp. were studied in 5-17-year-old Scots pine plantations in west-central Poland. Two infection centres (1.14$9.30 \mathrm{ha}$ ) in each of three forest districts (Siemianice, Zielonka and Złotów) were intensively sampled. Root collars were examined for mycelial fans, decayed wood, and rhizomorphs. Twenty two isolates of Armillaria ostoyae collected from epiphytic rhizomorphs from 20 living and two dead trees in the six infection centres were identified with somatic incompatibility group. Only one somatic incompatibility group for A. ostoyae was found. Twenty one isolates produced rhizomorphs on oak-wood discs submerged in a sand-forest soil substrate. Isolates from Siemianice formed the smallest rhizomorph networks and those from Złotów the most abundant. There were 16 different genets among 22 isolates of $A$. ostoyae distinguished by RAPD analysis. Genetic similarity among genets was $25.6-97.5 \%$. The large diversity in A. ostoyae suggests that sexual reproduction may occur in nature more often than expected.
\end{abstract}

Additional key words: Armillaria ostoyae, diversity, genets, RAPD-PCR, rhizomorphs

Addresses: W. Szewczyk, H. Kwaśna*, J. Behnke-Borowczyk, A. Ratajczak, A. Świetlik, Department of Forest Pathology, Faculty of Forestry, Poznań University of Life Sciences, Wojska Polskiego 71c, 60-625 Poznań, Poland, e-mail: kwasna@up.poznan.pl

J. Bocianowski, Department of Mathematical and Statistical Methods, University of Life Sciences, Wojska Polskiego 28, 60-625 Poznań, Poland

\section{Introduction}

Armillaria root rot can severely damage the root system of forest trees, causing reduced growth, predisposition to windthrow and tree mortality, with a consequent negative effect on commercial timber production. Armillaria ostoyae (Romagn.) Herink infects conifers of the Pinaceae Lindley. It is a common pathogen in Poland. In 2012 Armillaria root rot occurred on 99215 ha (Anonymous 2012). The rela- tive importance of $A$. ostoyae from a commercial point of view increases when conifers replace hardwoods (Guillaumin et al. 1993; Legrand and Guillaumin 1993).

Armillaria (Fr.) Staude is an obligate wood inhabitant, obtaining all its nutrients from the degradation of woody substrates. The fungus forms a highly differentiated root-like aggregation of hyphae. These rhizomorphs ramify through the soil, being fuelled by the mycelium growing in wood. Rhizomorphs 
also grow epiphytically along roots (Baumgartner and Rizzo 2001).

The ability to colonize a wood substrate and then to produce rhizomorphs that spread out into the surrounding soil enables Armillaria to form infection centres that can develop from a single tree to cover many hectares (Shaw and Roth 1976; Van der Kamp 1993; Peet et al. 1996; Ferguson et al. 2003).

Rhizomorphs are $1-5 \mathrm{~mm}$ in diam., have a melanized outer protective cortex layer and central gasfilled cavity and pores which allow them to translocate water and nutrients and participate in aeration and gas exchange (Granlund et al. 1984; Cairney et al. 1988; Pareek et al. 2001, 2006). Considering that they grow towards rather than away from the soil surface (Morrison 1976), they may help mycelium to respire in the low oxygen and high carbon dioxide environment beneath the root bark (Baumgartner et al. 2011). Rhizomorphs may affect the activity of other soil organisms, including mycorrhizal fungi (Leake et al. 2004).

Rhizomorphs are produced during various stages of wood decay, but the extent of growth is host species-dependent and influenced by habitat and environmental conditions, including composition and nutritional status of the soil and the presence of primary and secondary colonizers (Weinhold 1963; Pearce and Malajczuk 1990; Prospero et al. 2006). Rhizomorphs are formed mostly in the upper layer of the soil profile (A-B horizon up to $30 \mathrm{~cm}$ ) owing to their dependence on an adequate oxygen supply (Redfern 1973; Morrison 1976; Rishbeth 1978; Singh 1981).

The extent, development and functions of Armillaria rhizomorphs in undisturbed ecosystems have been described by Thompson and Rayner (1983). The behaviour of rhizomorphs in pure culture and their spatial distribution in soil have been studied in terms of nutrient translocation and growth strategies by Bolton and Boddy (1993), Mihail and Bruhn (2005), Watkinson et al. (2005) and Lamour et al. (2007).

Much effort has been made to understand the biology and the epidemiology of Armillaria. Morrison (1989, 2004) first observed that rhizomorph growth habit affects saprotrophic and pathogenic growth of Armillaria and its virulence.

The ecological significance of Armillaria rhizomorphs is still not fully recognized. One of the areas where further investigation is needed is the genetic basis of pathogenicity and virulence (Gregory et al. 1991), which is linked to the ability to form rhizomorphs. In further studies, Prospero et al. (2004) showed that the virulence of Swiss isolates of $A$. ostoyae on 2-year-old Norway spruce (Picea abies (L.) H.Karst) was positively correlated with its ability to produce rhizomorphs. Susceptibility of Norway spruce to A. ostoyae infection varied and depended on the provenance of the host. Infection by $A$. ostoyae was associated with significantly more lesions on roots than infection by $A$. cepistipes Velen. The virulence of $A$. ostoyae and A. cepistipes was not correlated with their wood-degrading capability.

Many studies on Armillaria have included population structure analyses. These often result in the identification of genets - genetically distinct secondary mycelia of the same species coexisting within a population. They are considered as units within a population. Knowledge of the size, distribution and behaviour of genets provides important information on the ecology, establishment, variation, activity and pathogenicity of Armillaria.

Studies on the population structure of pathogenic Armillaria species have been made in Canada, USA and Europe. In Canada, the most common species in nine infection centres in the central interior of British Columbia were A. ostoyae and Armillaria sinapina Bérubé \& Dessureault (Dettman and Kamp 2001). The population structure of $A$. ostoyae was consistent with a clonal reproductive strategy, and infection centres were occupied by single $A$. ostoyae genets or ramets. The population structure of $A$. sinapina resulted from more frequent basidiospore infections, and infection centres were occupied by multiple (18) genets. In the USA, the most common Armillaria species on six tree species in approximately 16100 ha of dry, mixed-conifer forest of the Blue Mountains of north-east Oregon was A. ostoyae (96.4\%) (Ferguson et al. 2003). Only $3.6 \%$ of isolates belonged to North American Biological Species X (NABS X). The most common species in more than $500 \mathrm{~km}^{2}$ of mixed oak forests of central Massachusetts was $A$. gallica Marxm. \& Romagn (Brazee et al. 2012). Here, there were 38 genets within 153 isolates. The genets ranged in distribution from 5 to 33 per hectare, with a mean of eight and the average genet occupying 0.13 ha. In the Swiss Alps, the incidence of $A$. ostoyae and A. cepistipes varied greatly (Prospero et al. 2004). Six genets were identified in each species. Genets of the same species overlapped rarely and only on the borders. There was strong intraspecific competition in both Armillaria species.

The objectives of this study were to investigate: (i) the incidence and population structure of Armillaria spp. in Scots pine plantations in west-central Poland; (ii) the ability of the Polish A. ostoyae isolates to produce rhizomorphs in vitro; (iii) effects of location on abundance of rhizomorphs produced; (iv) intraspecific genetic variability among $A$. ostoyae isolates; (v) reproductive strategy of $A$. ostoyae evaluated on the basis of its genetic variability. 


\section{Material and methods}

\section{Isolates}

The 22 isolates of Armillaria used in this study were obtained from epiphytic rhizomorphs attached to roots and were collected between 2005 and 2013 from six infection centres in more or less severely diseased 5-17-year-old Scots pine (Pinus sylvestris L.) plantations in Siemianice Forest District $\left(51.32083^{\circ} \mathrm{N} 16.91000^{\circ} \mathrm{E}\right)$, Zielonka Forest District $\left(52.5533^{\circ} \mathrm{N} 17.1133^{\circ} \mathrm{E}\right)$ and Złotów Forest District $\left(53.36346^{\circ} \mathrm{N} 17.04082^{\circ} \mathrm{E}\right)$. Isolates R3, R12 and R26 were from Siemianice I (2.95 ha), and R6, R27, R28 and R29 from Siemianice II (2.28 ha). Isolates R1 and R8 were from Zielonka I (9.30 ha), and R11, R13 and R30 from Zielonka II (3.52 ha). Isolates R4, R7, R14 and R15 were from Złotów I (3.60 ha), and R5, R9, R10, R16, R20 and R25 from Złotów II (1.14 ha). The infection centres in different Forest Districts were 300-400 km apart (Fig. 1, Table 1). The two infection centres in Siemianice were $50 \mathrm{~km}$ apart, in Zielonka $5 \mathrm{~km}$ apart and in Złotów $30 \mathrm{~km}$ apart. Characteristics of soils (top $30 \mathrm{~cm}$ of mineral soil) are in Table 1 . In all three locations the previous stand was composed of Scots pine (95-135 years old) with admixture of larch (Larix decidua Mill.), spruce (Picea abies (L.) H. Karst.) and oak (Quercus petraea (Mattuschka) Liebl.). In Siemianice and Zielonka the mean annual temperature was $7-9^{\circ} \mathrm{C}$ and in Złotów $6-7^{\circ} \mathrm{C}$, and annual precipitation was 700-800, 500 and 500-600 $\mathrm{mm}$, respectively.

Table 1. Characteristics of topsoil in the sample areas

\begin{tabular}{|c|c|c|c|}
\hline Soil characteristics & $\begin{array}{l}\text { Siemia- } \\
\text { nice }\end{array}$ & Zielonka & Złotów \\
\hline Texture & $\begin{array}{l}\text { Sandy } \\
\text { loam }\end{array}$ & $\begin{array}{l}\text { Sandy } \\
\text { loam }\end{array}$ & $\begin{array}{l}\text { Sandy } \\
\text { loam }\end{array}$ \\
\hline Sand:clay:silt & $54: 10: 36$ & $56: 12: 32$ & $55: 12: 33$ \\
\hline $\mathrm{pH}$ in $\mathrm{KCl}^{1}$ & 4.030 & 3.940 & 3.955 \\
\hline $\mathrm{pH}$ in $\mathrm{H}_{2} \mathrm{O}$ & 4.720 & 4.695 & 4.510 \\
\hline Organic carbon $(\%)^{2}$ & 0.357 & 0.553 & 0.419 \\
\hline Total nitrogen $(\%)^{3}$ & 0.040 & 0.056 & 0.046 \\
\hline $\mathrm{C}: \mathrm{N}$ & 8.92 & 9.87 & 8.91 \\
\hline $\begin{array}{l}\text { Extractable phosphorus } \mathrm{P}_{2} \mathrm{O}_{5} \\
(\mathrm{mg} / \mathrm{kg})^{4}\end{array}$ & 171.00 & 197.00 & 195.00 \\
\hline $\begin{array}{l}\text { Extractable potassium (mg/ } \\
\mathrm{kg})^{5}\end{array}$ & 10.95 & 12.10 & 10.00 \\
\hline $\begin{array}{l}\text { Extractable magnesium (mg/ } \\
\mathrm{kg})^{5}\end{array}$ & 1.05 & 1.35 & 1.00 \\
\hline Extractable calcium $(\mathrm{mg} / \mathrm{kg})^{5}$ & 4.30 & 4.30 & 5.10 \\
\hline Extractable sodium $(\mathrm{mg} / \mathrm{kg})^{5}$ & 0.75 & 1.00 & 0.90 \\
\hline
\end{tabular}

1 - analysed with potentiometer according to norm PN-ISO 103390:1997

2 - analysed chemically according to norm PN-ISO 10694:2002

${ }^{3}$ - analysed chemically according to norm PN-13878:2002

${ }^{4}$ - analysed chemically with method of Egner-Riehm

5 - analysed chemically according to procedure PB-05 ed.2

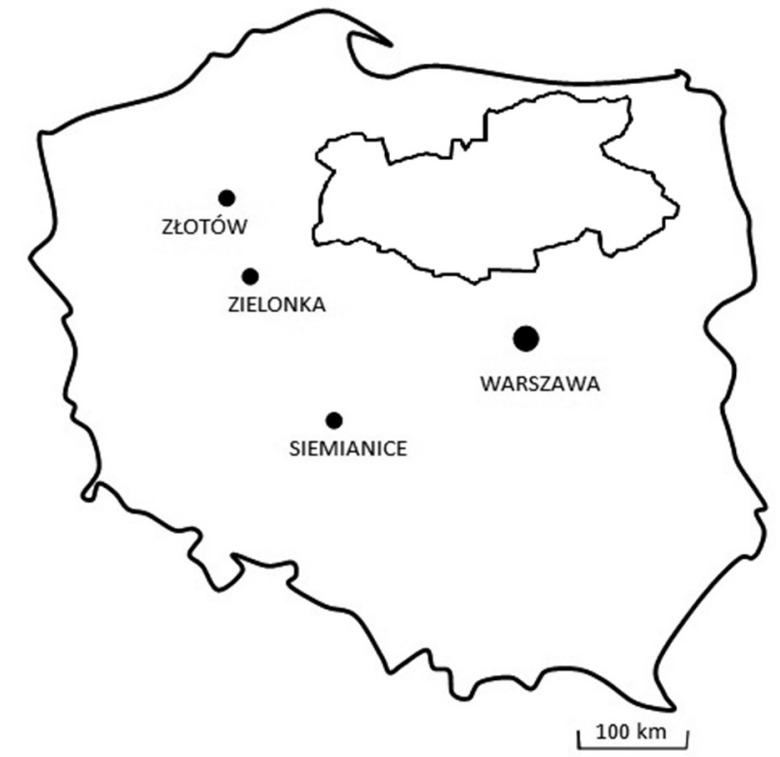

Fig. 1. Map of Poland with infection centres in Siemianice, Zielonka and Złotów Forest Districts

At each infection centre, four plots were randomly established. From each plot centre, a variable radius (20-50 m) was established to locate isolates of Armillaria, primarily from living trees exhibiting symptoms and signs of infection (chlorotic needles, dieback of twigs, layer of resin, debris, and fungal tissue forming at the trunk base or around infected roots, white mycelial mats and rhizomorphs under bark, or clusters of fruit bodies at the base of the infected tree) or recently killed trees. Mean plot size was 0.48 ha with a range of $0.12-0.85$ ha. The total area of all 24 plots sampled was 11.52 ha. The infection centres were surrounded by areas with no symptoms of disease. The number of isolates collected depended on the severity of Armillaria infection, which was low at Zielonka (10\% diseased trees per plot), moderate at Siemianice (10-20\%) and high at Złotów ( $\geq 20 \%)$.

Within $12 \mathrm{~h}$ after collection, each rhizomorph was surface sterilized in sodium hypochlorite ( $7 \%$ active chlorine) for 15-30 s and rinsed twice in sterile, demineralized water for $>15 \mathrm{~s}$. The pieces were dried between paper towels and placed on $2 \%$ malt extract agar (MEA: Difco malt extract $20 \mathrm{~g} \mathrm{l}^{-1}$, Bacto Agar $15 \mathrm{~g} \mathrm{l}^{-1}$, thiabendazole $230 \mathrm{mg} \mathrm{l}^{-1}$ (added in $1 \mathrm{ml}$ concentrated lactic acid, 85-90\%), streptomycin 100 $\mathrm{mg}^{-1}$, polymyxin sulphate $50 \mathrm{mg}^{-1}$ and benzylpenicillin sodium $100 \mathrm{mg} \mathrm{1}^{-1}$; modified from Legrand and Guillaumin 1993). Cultures were incubated in the dark at $25^{\circ} \mathrm{C}$ and subcultured as necessary. 


\section{Identification of Armillaria with somatic incompatibility tests}

The Armillaria isolates were identified using somatic incompatibility tests following the methods described by Korhonen (1978). Mating tests were performed on $2 \%$ malt yeast extract agar (MYEA: Difco malt extract $20 \mathrm{~g} \mathrm{l}^{-1}$, yeast extract $2 \mathrm{~g} \mathrm{l}^{-1}$, agar $20 \mathrm{~g}$ $1^{-1}$ ) in Petri dishes. Each of the unknown 22 isolates was paired with a haploid tester (monospore isolate) of each of $A$. borealis Marxm. \& Korhonen, A. cepistipes, A. gallica, A. mellea (Vahl) P. Kumm., A. ostoyae and A. tabescens (Scop.) Emel. Plates were incubated at $25^{\circ} \mathrm{C}$ in the dark for 4 weeks. The mating reaction was scored on the basis of the appearance of the mycelium. If the two cultures were confluent, this indicated that the isolates were the same species (the same so- matic incompatibility group). A gap between the two cultures, with a reaction zone consisting of sparse to absent mycelia (i.e. mutual inhibition) indicated an antagonistic reaction between two genetically distinct isolates (Korhonen 1978; Dettman 1999). Paired cultures were examined every seven days until a clear and obvious compatibility or incompatibility reaction was observed. Any pairing that gave ambiguous or intermediate results was repeated.

Somatic incompatibility tests with diploid isolates of Armillaria collected throughout the plots were done to distinguish genetically distinct individuals (genets) within A. ostoyae (Shaw and Roth 1976). Mycelial plugs of isolates were placed $4 \mathrm{~mm}$ apart on $2 \%$ MYEA and plates were incubated at $25^{\circ} \mathrm{C}$ in the dark for 4 weeks. Isolates from the same plot were paired in all possible combinations, including self-pairings

Table 2. Effect of location on A. ostoyae rhizomorph production

\begin{tabular}{|c|c|c|c|c|c|c|c|c|c|c|}
\hline \multirow{2}{*}{$\begin{array}{l}\text { Infection } \\
\text { centre }\end{array}$} & \multirow{2}{*}{$\begin{array}{l}\text { Previous } \\
\text { forest type }\end{array}$} & \multirow[t]{2}{*}{ Isolate } & \multicolumn{2}{|c|}{$\begin{array}{c}\text { Number of rhizo- } \\
\text { morphs }\end{array}$} & \multicolumn{2}{|c|}{$\begin{array}{c}\text { Number of rhizo- } \\
\text { morph apices }\end{array}$} & \multicolumn{2}{|c|}{$\begin{array}{l}\text { Rhizomorph length } \\
(\mathrm{mm})\end{array}$} & \multicolumn{2}{|c|}{$\begin{array}{l}\text { Rhizomorph dry } \\
\text { weight (mg) }\end{array}$} \\
\hline & & & Mean & S.D. & Mean & S.D. & Mean & S.D. & Mean & S.D. \\
\hline \multirow{3}{*}{ Siemianice I } & \multirow{4}{*}{$\begin{array}{c}\text { Fresh } \\
\text { broadleaf } \\
\text { forest }(\mathrm{FBF})\end{array}$} & R3 & $3.67 c$ & 4.72 & $6.33 b$ & 5.43 & $72.80 c$ & 62.60 & $2.83 b$ & 2.14 \\
\hline & & $\mathrm{R} 12$ & $12.83 b c$ & 15.57 & $18.67 b$ & 24.78 & $192.30 c$ & 238.40 & $27.33 b$ & 55.72 \\
\hline & & $\mathrm{R} 26$ & $10.43 b c$ & 13.51 & $15.42 b$ & 20.43 & $168.20 c$ & 198.60 & $17.48 b$ & 35.92 \\
\hline Mean & & & 8.97 & 11.26 & 13.47 & 16.88 & 144.43 & 166.53 & 15.88 & 31.26 \\
\hline \multirow{4}{*}{ Siemianice II } & \multirow{5}{*}{$\begin{array}{l}\text { Fresh mixed } \\
\text { broadleaf for- } \\
\text { est (FMBF) }\end{array}$} & $\mathrm{R} 6$ & $6.17 b c$ & 10.57 & $8.17 b$ & 13.59 & $72.70 c$ & 126.70 & $2.17 b$ & 3.92 \\
\hline & & $\mathrm{R} 27$ & $10.23 b c$ & 13.27 & $16.42 \mathrm{~b}$ & 14.88 & $70.17 c$ & 122.52 & $2.12 \mathrm{~b}$ & 3.90 \\
\hline & & $\mathrm{R} 28$ & $8.98 b c$ & 13.81 & $15.56 \mathrm{~b}$ & 16.53 & $57.25 c$ & 124.12 & $1.98 b$ & 3.32 \\
\hline & & $\mathrm{R} 29$ & $8.26 b c$ & 10.60 & $8.27 b$ & 16.23 & $71.71 \mathrm{c}$ & 116.43 & $1.87 \mathrm{~b}$ & 2.92 \\
\hline Mean & & & 8.41 & 12.06 & 12.10 & 15.30 & 67.95 & 122.44 & 2.03 & 3.51 \\
\hline \multirow{2}{*}{ Zielonka I } & \multirow{3}{*}{$\begin{array}{c}\text { Fresh } \\
\text { broadleaf } \\
\text { forest }(\mathrm{FBF})\end{array}$} & $\mathrm{R} 1$ & $37.33 \mathrm{bc}$ & 27.65 & $55.00 \mathrm{~b}$ & 47.34 & $1296.80 b$ & 893.10 & $48.33 b$ & 33.40 \\
\hline & & $\mathrm{R} 8$ & $10.67 b c$ & 13.38 & $10.83 b$ & 13.76 & $34.50 c$ & 45.20 & $0.75 b$ & 0.69 \\
\hline Mean & & & 24.0 & 20.51 & 32.91 & 30.52 & 665.65 & 469.15 & 24.54 & 17.04 \\
\hline \multirow{3}{*}{ Zielonka II } & \multirow{4}{*}{$\begin{array}{l}\text { Fresh mixed } \\
\text { broadleaf for- } \\
\text { est (FMBF) }\end{array}$} & $\mathrm{R} 11$ & $19.67 \mathrm{bc}$ & 20.82 & $20.33 b$ & 21.39 & $137.70 \mathrm{c}$ & 146.10 & $4.17 b$ & 4.57 \\
\hline & & $\mathrm{R} 13$ & $9.00 \mathrm{bc}$ & 19.26 & $10.00 \mathrm{~b}$ & 20.00 & $76.30 c$ & 152.40 & $4.00 \mathrm{~b}$ & 8.00 \\
\hline & & $\mathrm{R} 30$ & $14.25 b c$ & 10.58 & $15.45 b$ & 20.67 & $100.53 c$ & 151.15 & $3.98 b$ & 7.88 \\
\hline Mean & & & 14.30 & 16.88 & 15.26 & 20.68 & 104.84 & 149.88 & 4.05 & 6.81 \\
\hline \multirow{4}{*}{ Złotów I } & \multirow{5}{*}{$\begin{array}{l}\text { Fresh mixed } \\
\text { broadleaf for- } \\
\text { est (FMBF) }\end{array}$} & $\mathrm{R} 4$ & $50.00 \mathrm{~b}$ & 42.79 & $54.17 \mathrm{~b}$ & 47.60 & $764.20 \mathrm{bc}$ & 706.10 & $24.17 b$ & 24.85 \\
\hline & & $\mathrm{R} 7$ & $1.50 c$ & 1.76 & $1.5 \mathrm{~b}$ & 1.76 & $4.00 c$ & 4.60 & $0.25 b$ & 0.27 \\
\hline & & $\mathrm{R} 14$ & $13.17 b c$ & 10.96 & $14.17 \mathrm{~b}$ & 11.18 & $84.20 c$ & 59.60 & $2.83 b$ & 2.56 \\
\hline & & $\mathrm{R} 15$ & $0.00 c$ & 0.00 & $0.00 \mathrm{~b}$ & 0.00 & $0.00 c$ & 0.00 & $0.00 \mathrm{~b}$ & 0.00 \\
\hline Mean & & & 21.55 & 18.50 & 23.28 & 20.18 & 284.13 & 256.76 & 9.08 & 9.22 \\
\hline \multirow{6}{*}{ Złotów II } & \multirow{8}{*}{$\begin{array}{c}\text { Fresh } \\
\text { broadleaf } \\
\text { forest (FBF) }\end{array}$} & $\mathrm{R} 5$ & $116.00 \mathrm{a}$ & 26.08 & $147.00 \mathrm{a}$ & 33.56 & $2327.80 a$ & 863.70 & $269.67 a$ & 224.61 \\
\hline & & R9 & $22.50 b c$ & 40.80 & $28.17 b$ & 49.77 & $172.50 c$ & 90.60 & $9.50 \mathrm{~b}$ & 7.04 \\
\hline & & $\mathrm{R} 10$ & $96.00 \mathrm{a}$ & 36.54 & $121.83 \mathrm{a}$ & 51.94 & $2290.00 \mathrm{a}$ & $\begin{array}{c}1 \\
074.70\end{array}$ & $114.67 \mathrm{~b}$ & 65.56 \\
\hline & & $\mathrm{R} 16$ & $12.17 \mathrm{bc}$ & 14.59 & $13.33 b$ & 15.54 & $82.70 c$ & 95.10 & $2.42 \mathrm{~b}$ & 3.83 \\
\hline & & $\mathrm{R} 20$ & $32.33 b c$ & 23.09 & $40.33 b$ & 27.81 & $665.20 b c$ & 470.60 & $28.50 b$ & 20.08 \\
\hline & & $\mathrm{R} 25$ & $8.33 b c$ & 10.86 & $10.33 b$ & 15.13 & $108.70 c$ & 175.60 & $12.50 \mathrm{~b}$ & 28.18 \\
\hline \multirow[t]{2}{*}{ Mean } & & & 47.88 & 25.32 & 60.16 & 32.29 & 941.15 & 461.71 & 72.87 & 58.21 \\
\hline & & $\mathrm{LSD}_{0.001}$ & 44.32 & & 56.59 & & 904.90 & & 117.85 & \\
\hline \multicolumn{11}{|c|}{ Mean squares from analysis of variance } \\
\hline Isolate & & & $6498.2^{* *}$ & & $10480.1^{* *}$ & & $3512.6^{* *}$ & & $27223^{* *}$ & \\
\hline Residual & & & 507.2 & & 826.8 & & 211.3 & & 3586 & \\
\hline
\end{tabular}

Different letters $(\mathrm{a}, \mathrm{b}, \mathrm{c})$ indicate statistically significant differences between isolates (ANOVA, $P<0.001$ or $P<0.05$ ).

**Significant at $P<0.001$. 
as controls. Two isolates were identified as belonging to the same somatic incompatibility group (SIG) (Rizzo and Harrington 1993) if they merged to form a single colony. A line of demarcation between the cultures indicated somatic incompatibility. Once SIGs were identified within plots, pairings were done between isolates from different plots.

\section{Production of rhizomorphs in oak segments}

Discs ( $2 \mathrm{~cm}$ diameter, $1 \mathrm{~cm}$ long) from live, freshly cut branches of 20-year-old Quercus robur L. were used as a woody substrate to produce rhizomorphs in vitro. The discs were washed with $70 \%$ ethanol and autoclaved twice at $121^{\circ} \mathrm{C}$ for $60 \mathrm{~min}$. Next, the discs were placed onto 20-day-old A. ostoyae cultures growing on $2 \%$ MEA in Petri dishes and incubated in the dark at $22^{\circ} \mathrm{C}$ for 30 days. Four discs were inoculated with each of the 22 Armillaria isolates. When the discs became covered with white-cream to light-brown A. ostoyae mycelium they were placed in non-sterile moist river sand in sealed jars. After 14 weeks of incubation in the dark at $22^{\circ} \mathrm{C}$ (Rishbeth 1982, 1984), when $A$. ostoyae was well established and initial, single, short rhizomorphs had formed on the surface of the discs, the discs were carefully transferred from the jars to plastic bags containing a substrate consisting of forest soil, sand and humus (1:1:1). The composition of this substrate resembled the composition of the forest soil and was intended to induce the formation of fully melanized rhizomorphs. After 10 weeks in the dark at $23^{\circ} \mathrm{C}$, the number of rhizomorphs, number of rhizomorph apices, rhizomorph length $(\mathrm{mm})$, and dry weight of rhizomorphs (mg) were determined (Eakomy 1998). The results are presented as the mean of four replicates (four wood pieces inoculated with one isolate) from one jar.

\section{DNA extraction}

Isolates were grown in $2 \%$ malt extract broth (MEB: Difco malt extract $20 \mathrm{~g}^{-1}$ ) at $24^{\circ} \mathrm{C}$ in the dark for 3 weeks. The mycelium was harvested with a strainer, lyophilized and ground to a fine powder in liquid nitrogen. Extraction buffer $(1 \mathrm{ml} ; 100 \mathrm{mM}$ Tris-Cl pH 8.4, 1.4 M NaCl, 25 mM EDTA pH 8, 2\% CTAB, hexadecyltrimethylammonium bromide) was added to $\sim 0.5 \mathrm{~g}$ powdered mycelium and incubated at $60^{\circ} \mathrm{C}$ for 2 hours. The mycelium powder-buffer suspension was divided into two parts and centrifuged (17 $900 \mathrm{~g}, 20 \mathrm{~min}$ ) to remove cell debris. Isoamyl alcohol:chloroform (1:24 v/v) extractions were performed on the aqueous phase until a clean interphase was obtained. Nucleic acids were precipitated using $96 \%$ ice-cold ethanol. The precipitate was col- lected by centrifugation (17 $900 \mathrm{~g}, 30 \mathrm{~min}$ ), washed with cold $70 \%$ ethanol, dried, and eluted in sterile distilled water. Contaminating RNA was removed by adding RNAse A $\left(0.01 \mathrm{mg} \mathrm{ml}^{-1}\right.$ ) (Roche Diagnostics, Mannheim, Germany).

\section{RAPD-PCR assay}

Random amplified polymorphic DNA (RAPD) analysis was applied to detect polymorphisms in $A$. ostoyae isolates and to distinguish $A$. ostoyae genets. Seven decamer oligonucleotides $\left(5^{\prime}-3^{\prime}\right)$ were used: OPA-1 (CAGGCCCTTC), OPA-2 (TGCCGAGCTG), OPA-3 (AGTCAGCCAC), OPA-4 (AATCGCGCTG), R-25 (CCCGGCCTTCC), R-28 (ATGGATCCGC) and UBC-31 (CCCGGCCTTCC), obtained from oligo.pl (Institute of Biochemistry and Biophysics, Polish Academy of Science). These oligonucleotides were selected on the basis of high-intensity bands, hypervariability, and good definition of amplified DNA fragments, and have been used for molecular characterization and detection of polymorphisms in Armillaria spp. by Smith et al. (1992), Guillaumin et al. (1996), Schulze et al. (1997) and Dettman and van der Kamp (2001). RAPD analysis generally followed the method of Williams et al. (1990). The final RAPD-PCR reaction concentrations were: $2.0 \mathrm{mM}$ $\mathrm{MgCl}_{2}, 100 \mu \mathrm{M}$ deoxynucleotide triphosphates, 0.2 $\mu \mathrm{M}$ primer, 2.0 units Taq polymerase, $10 \times$ PCR buffer, 10 ng DNA template, with a final volume of 25 $\mu \mathrm{l}$ per reaction tube. Cycling conditions were: initial denaturation step at $94^{\circ} \mathrm{C}$ for $5 \mathrm{~min}$, followed by 35 cycles of $94^{\circ} \mathrm{C}$ for $1 \mathrm{~min}, 40^{\circ} \mathrm{C}$ for $30 \mathrm{~s}, 72^{\circ} \mathrm{C}$ for 30 $\mathrm{s}$, and then cooling at $4^{\circ} \mathrm{C}$. Amplification was carried out in a T3 thermocycler (Biometra, GmbH, Göttingen Germany). The amplification products were separated on $1.5 \%$ agarose gels at $4.75 \mathrm{~V} / \mathrm{cm}$, stained with ethidium bromide, and photographed under ultraviolet illumination. Only bands that were clearly resolved and consistent across all amplifications were recorded. The molecular weight of each band was estimated by comparing gel migration distances with those of the PCR marker, 50-2 000 bp (SIGMA, Cat. No. P9577, Saint Louis, MO 63103, USA). Each RAPD pattern describes a single genet.

\section{Statistical analysis}

To determine whether isolates collected from different locations differed in their ability to produce rhizomorphs in vitro, the number of rhizomorphs, number of rhizomorph apices, length of rhizomorph and dry weight of rhizomorphs were analysed with one-way analysis of variance (ANOVA, $P<0.001$ or $P<0.05)$. The least significant differences (LSDs) for each variable were calculated and homogeneous groups for number of rhizomorphs, number of rhizo- 


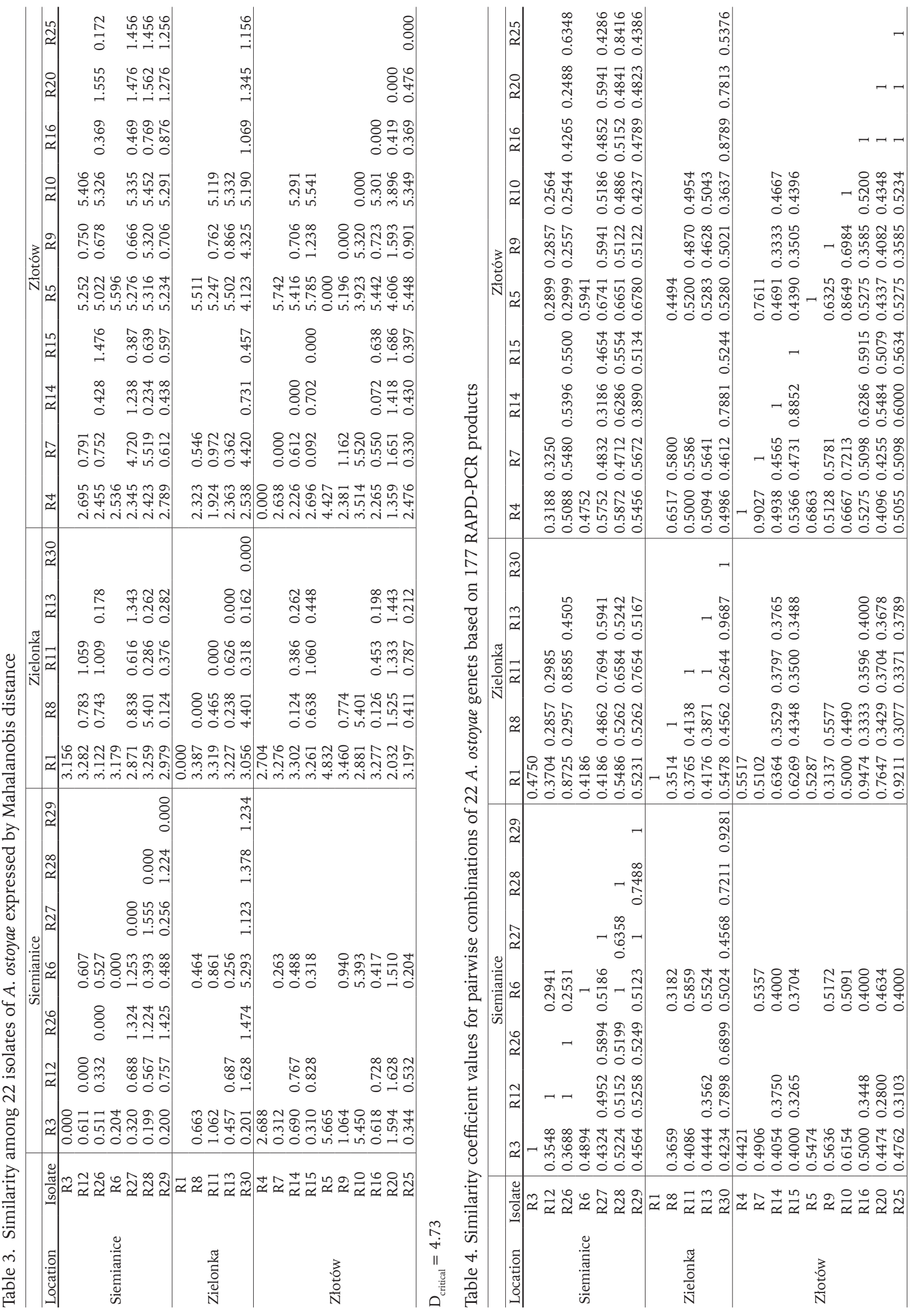


morph apices, length of rhizomorph and dry weight of rhizomorphs were determined. Similarity between each pair of evaluated isolates with respect to the four parameters analysed was expressed by Mahalanobis distance. This method provides a relative measure of a data point's distance (residual) from a common point. It is used to identify and gauge similarity of an unknown sample set to a known one. It takes into account the correlations of the data set and is scale-invariant. It has a multivariate effect size, more effective than principal component analysis (Mahalanobis 1936; Seidler-Łożykowska and Bocianowski 2012). The Mahalanobis distance was suggested as a measure of "polytrait" object similarity, whose significance was verified by means of critical value $\mathrm{D}_{\text {critical }}$ called "the least significant distance". Graphical distribution of isolates on a plane, considering all the parameters, was possible through the application of canonical variates analysis (Camussi et al. 1985). The relationship among the parameters was analysed using correlation coefficients (Kozak et al. 2010). The coefficients of genetic similarity (S) of the isolates were calculated using the formula of Nei and Li (1979). The association between molecular markers (genetic loci indicated by bands) and the number of rhizomorphs, number of rhizomorph apices, length of rhizomorphs and weight of rhizomorphs for the 22 isolates was estimated using regression analysis (Hastie and Tibshirani 1990). The molecular markers were treated as independent variables and considered in individual models. Data analysis was performed using the statistical package GenStat v. 7.1

\section{Results}

\section{Isolates}

Two infection centres for Armillaria root rot were identified in the 5-17 year-old plantations of Scots pine in each of the three forest districts (Siemianice, Zielonka and Złotów) in west-central Poland. Twenty two isolation attempts from epiphytic rhizomorphs taken from these infection centres yielded 22 viable cultures of Armillaria (Table 2).

\section{Identification of Armillaria with somatic incompatibility tests}

In somatic incompatibility tests performed with six testers representing six European Armillaria spp., the tested isolates produced confluent mycelium only with the $A$. ostoyae tester indicating that all 22 isolates were $A$. ostoyae. In somatic incompatibility tests performed for all within-centre and between-centre pairings, the tested isolates formed homogenous col- onies with no dark lines or other barrier zones, indicating that they belong to one and the same somatic incompatibility group of $A$. ostoyae.

\section{Production of rhizomorphs in oak segments}

Twenty one out of 22 A. ostoyae isolates initiated rhizomorphs in soil in vitro. Isolate R15 (from Złotów I) did not produce rhizomorphs despite mycelial growth on/within the oak discs. The branching pattern of the rhizomorphs was dichotomous. Each rhizomorph network grew from one or several initials formed on the oak disc. The mean number of rhizomorphs produced was 8.41-47.88, the number of rhizomorph apices was 12.10-60.16, rhizomorph length was $67.95-941.15 \mathrm{~mm}$ and rhizomorph dry weight was $2.03-72.87 \mathrm{mg}$ (Table 2). Isolates from Siemianice and Złotów formed, respectively, the smallest and the largest rhizomorph networks. The individual rhizomorph parameters were often similar in isolates from Siemianice and Zielonka, and often significantly different (ANOVA, $P<0.001$ ) from isolates from Złotów. Among isolates from Złotów there were four homogeneous groups for number of rhizomorphs, three for rhizomorph length, and two homogeneous groups each for number of rhizomorph apices and rhizomorph weight. The two isolates with most similarity expressed by the smallest Mahalanobis distance (0.072) were from Złotów I (R14 and R16, Table 3). The two isolates with the least similarity (Mahalanobis distance $=5.785)$ were from Złotów II (R5) and Złotów I (R15). Similarities and differences among isolates with respect to the four parameters analysed are illustrated in Fig. 2, which presents the dispersion of isolates on a plane in the system of the first two canonical variates. The first and second canonical variates elucidated $74.76 \%$ and $18.38 \%$ of the multivariate variability of the isolates, revealing that isolates R1 (Zielonka I), R4 (Złotów I) and R5, R10, R20 (Złotów II) are different from each other and are different from the other 17 isolates, which grouped together. The relationship between all four of the rhizomorph parameters analysed was shown by the positive and significant correlation coefficients $0.88-0.99$ (at $P<0.001$, data not presented).

The seven random amplified polymorphic DNA (RAPD) primers used to characterize the $22 \mathrm{~A}$. ostoyae isolates yielded a total of 177 bands (10-27 per primer), of which 153 were polymorphic (Fig. 3). Their products ranged in size from 260 to $2000 \mathrm{bp}$. Each primer produced 8-15 different bands. Eleven isolates produced five RAPD patterns: R6 and R28, R12 and R26, R27 and R29 from Siemianice; R11 and R13 from Zielonka; R16, R20 and R25 from Złotów. Isolates with the same RAPD patterns were located 
within areas of 1.14-3.52 ha. The other 11 isolates produced different RAPD patterns. Isolates with the same RAPD pattern were considered as identical. Based on the RAPD patterns, 16 distinct multilocus genets were detected among the $22 \mathrm{~A}$. ostoyae isolates. Each genet consisted of 1-3 isolates. The similarity coefficient values for the $22 \mathrm{~A}$. ostoyae pairwise genotype combinations (0.2488-0.975) showed genetic similarity between genets ranging from 24.88 to $97.50 \%$ (Table 4 ). The similarity coefficient was $\geq$ 0.500 for only $47 \%$ of pairwise genet combinations. The degrees of genetic similarity between isolate R1 (Zielonka I) and isolates R16 and R25 (Złotów II) were among the highest, even though they originated from two infection centres located $200 \mathrm{~km}$ apart.

Significant associations between nine markers (genetic loci) and the number of rhizomorphs and number of rhizomorph apices were demonstrated by regression analyses (Table 5). The percentage variation accounted for in regressions on number of rhizomorphs ranged from $23.0 \%$ for OPA2-40 and OPA241 to $52.4 \%$ for OPA4-101. The percentage variation accounted for in regressions on the number of rhizomorph apices ranged from $20.4 \%$ for OPA3-58 to $53.4 \%$ for OPA4-101. Significant associations were found between eight markers and rhizomorph length and between three markers and rhizomorph weight (Tables 6, 7). The percentage variation accounted for in regressions on rhizomorph length ranged from $21.5 \%$ for OPA3-59 to $43.1 \%$ for OPA4-101. In regressions on rhizomorph weight, the percentage variation accounted for ranged from $18.6 \%$ for OPA3-59 to $45.6 \%$ for OPA4-101.

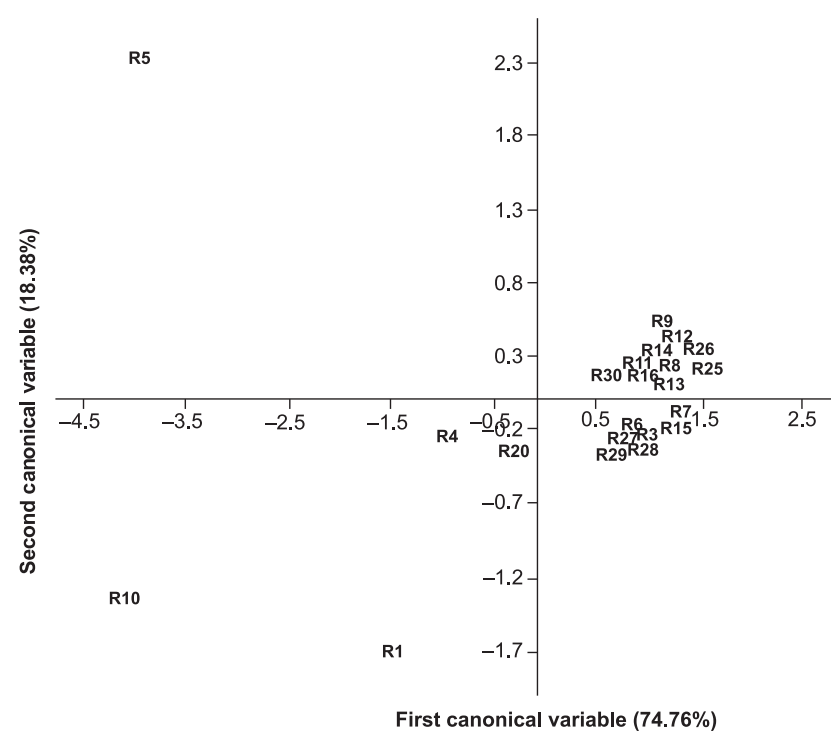

Fig. 2. Distribution of isolates in the plane of the first two canonical variables calculated for the four traits together: number of rhizomorphs, number of rhizomorph apices, length of rhizomorph and dry weight of rhizomorphs

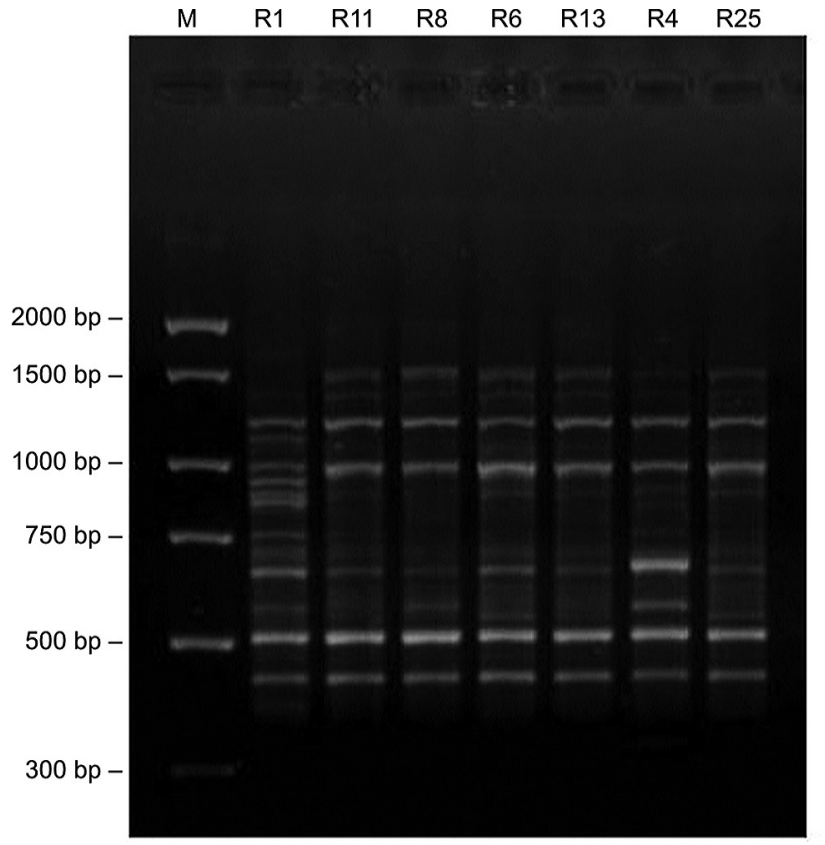

Fig. 3. Armillaria ostoyae RAPD-PCR products amplified by primer OPA-4. Lane M shows PCR marker

\section{Discussion}

Armillaria ostoyae was the only Armillaria species found in the six 5-17-year-old Scots pine plantations in the three forest districts in west-central Poland. This agrees with Żółciak (2007), who found only one species of Armillaria (A. ostoyae) in Scots pine in Poland. She analysed 356 samples from 105 infection centres located all over Poland. Members of Pinaceae are the main hosts for A. ostoyae and in Scots pine plantations the fungus is usually the primary and dominant pathogen. Generally, once Armillaria is established in a root system, secondary infection may occur via direct root-root contact and grafts with non-infected trees, via rhizomorphs growing through the soil or airborne basidiospores in autumn (Redfern and Filip 1991). Absence of other Armillaria species seems to result from strong competitive properties of $A$. ostoyae. It seems to inhibit the spread of other Armillaria species, restricting them to relatively small sizes (Dettman and van der Kamp 2001). We expected to find A. cepistipes, which may occur sympatrically with $A$. ostoyae in the same stand (Legrand et al. 1996; Marxmüller and Holdenrieder 2000; Prospero et al. 2003). This species was not recorded, however. It is considered rare in Poland and, according to Żółciak (2007), is restricted to Norway spruce (Picea abies (L.) H. Karst) and fir (Abies alba Mill.).

We showed that majority of our A. ostoyae isolates (21 out of 22) formed rhizomorphs on oak wood submerged in a substrate based on sand and forest soil. One isolate failed to form rhizomorphs. This is not unusual. Failure of certain isolates of $A$. ostoyae to produce rhizomorphs was also observed by Prospero 
Table 5. Molecular markers associated with number of rhizomorphs and number of rhizomorph apices of $A$. ostoyae isolates

\begin{tabular}{|c|c|c|c|c|c|c|c|c|}
\hline \multirow[b]{2}{*}{$\begin{array}{l}\text { Molecular } \\
\text { marker }\end{array}$} & \multicolumn{4}{|c|}{ Number of rhizomorphs } & \multicolumn{4}{|c|}{ Number of rhizomorph apices } \\
\hline & $\begin{array}{l}\text { Estimate of } \\
\text { regression } \\
\text { coefficient }\end{array}$ & $P$ & $\begin{array}{l}\% \text { variation } \\
\text { accounted }\end{array}$ & $\begin{array}{l}\text { S.E. of observa- } \\
\text { tions }\end{array}$ & $\begin{array}{l}\text { Estimate of } \\
\text { regression } \\
\text { coefficient }\end{array}$ & $P$ & $\begin{array}{l}\% \text { variation } \\
\text { accounted }\end{array}$ & $\begin{array}{l}\text { S.E. of obser- } \\
\text { vation }\end{array}$ \\
\hline OPA2-23 & 73.8 & 0.024 & 24.9 & 28.5 & 94.4 & 0.023 & 25.4 & 36.1 \\
\hline OPA2-25 & 42.4 & 0.018 & 27.2 & 28.1 & 54.5 & 0.017 & 28.0 & 35.5 \\
\hline OPA2-32 & 73.8 & 0.024 & 24.9 & 28.5 & 94.4 & 0.023 & 25.4 & 36.1 \\
\hline OPA2-34 & 73.8 & 0.024 & 24.9 & 28.5 & 94.4 & 0.023 & 25.4 & 36.1 \\
\hline OPA2-40 & 37.0 & 0.030 & 23.0 & 28.9 & 46.1 & 0.033 & 21.9 & 36.9 \\
\hline OPA2-41 & 37.0 & 0.030 & 23.0 & 28.9 & 46.1 & 0.033 & 21.9 & 36.9 \\
\hline OPA3-58 & 35.4 & 0.029 & 23.3 & 28.8 & 42.7 & 0.039 & 20.4 & 37.3 \\
\hline OPA3-59 & 40.1 & 0.016 & 28.2 & 27.9 & 48.3 & 0.024 & 24.8 & 36.2 \\
\hline OPA4-101 & 62.5 & $<0.001$ & 52.4 & 23.3 & 80.2 & $<0.001$ & 53.4 & 29.3 \\
\hline
\end{tabular}

et al. (2004). In their studies, $83.4 \%$ of the $A$. ostoyae isolates formed rhizomorphs on hazel (Corylus avellana L.) segments placed in soil substrate composed of peat and wood fibre $(80 \%+20 \%)$ amended with slow-release fertilizer and horn powder. The oakwood discs used in our study proved to be a good substrate for rhizomorph formation. When inoculated with $A$. ostoyae and placed in moist river sand the first initial rhizomorphs developed after 14 weeks, in the initial stage of wood decay. Prospero et al. (2004) observed single rhizomorphs after 30 months when using colonized hazel segments for inoculation of Scots pine seedlings in pots.

Generally, the nutritional and environmental status of the original location can affect future Armillaria behaviour. Good nutrition and favourable soil conditions, preferably with higher acidity and lower moisture, may have positive effects on future activity, including the formation of rhizomorphs (Morrison 1974, 1976; Redfern 1978). Isolates from Siemianice and Złotów produced, respectively, the smallest and the most abundant rhizomorph networks. These differences probably did not result from differences in the nutritional status of soil or previous forest type since these were similar. Less annual precipitation was recorded for Złotów, however. Adaptation of the local A. ostoyae to dryer conditions may result in the development of a more abundant rhizomorph net-

Table 6. Molecular markers associated with length of rhizomorphs of $A$. ostoyae isolates

\begin{tabular}{ccccc}
\hline $\begin{array}{c}\text { Molecular } \\
\text { marker }\end{array}$ & $\begin{array}{c}\text { Estimate of } \\
\text { regression } \\
\text { coefficient }\end{array}$ & $P$ & $\begin{array}{c}\text { \% variation } \\
\text { accounted }\end{array}$ & $\begin{array}{c}\text { S.E. of ob- } \\
\text { servation }\end{array}$ \\
\hline OPA2-23 & 1909 & 0.010 & 32.4 & 629 \\
OPA2-25 & 923 & 0.030 & 23.0 & 671 \\
OPA2-32 & 1909 & 0.010 & 32.4 & 629 \\
OPA2-34 & 1909 & 0.010 & 32.4 & 629 \\
OPA3-59 & 837 & 0.035 & 21.5 & 678 \\
UBC31-74 & 815 & 0.044 & 22.0 & 707 \\
UBC31-76 & 815 & 0.044 & 22.0 & 707 \\
OPA4-101 & 1335 & 0.003 & 43.1 & 593 \\
\hline
\end{tabular}

work in the substrate, which dried slowly but continuously over 24 weeks in jars and plastic bags.

Eleven isolates produced five RAPD patterns and belonged to the same five genets (2-3 isolates per genet). The other 11 isolates belonged to separate genets. This suggests high variation in these populations of A. ostoyae. Genets of pathogenic A. ostoyae are usually significantly larger than those of saprotrophic Armillaria species (Bendel 2006), and detection of so much variation was unexpected. A similarity coefficient was used to assess genetic variability among genets. When the presence or absence of RAPD markers (bands) produced by the seven primers was analysed, the similarity coefficient values produced for pairwise genet combinations of the $22 \mathrm{~A}$. ostoyae were $0.2488-0.975$ and were similar to the range (0.333-0.950) reported by Dettman and van der Kamp (2001) for pairwise genet combinations of 21 A. ostoyae isolates. Therefore similar variation was obtained with a similar number of isolates by us and Dettman and van der Kamp (2001). It was also noted that greater genetic similarity was often associated with geographic spatial proximity. This also agrees with Dettman and van der Kamp (2001) who reported an association between genetic similarity and spatial proximity of $A$. ostoyae genets in British Columbia (Canada).

The frequent occurrence of separate genets of $A$. ostoyae in three locations in Poland is not fully consistent with the general reproductive strategy of Armillaria, which is 'clonal' (vegetative, mitotic from an original initial mycelium). The dominance of 'clonal' reproduction of Armillaria in western United

Table 7. Molecular markers associated with dry weight of rhizomorphs of $A$. ostoyae isolates

\begin{tabular}{ccccc}
\hline $\begin{array}{c}\text { Molecular } \\
\text { markers }\end{array}$ & $\begin{array}{c}\text { Estimate of } \\
\text { regression } \\
\text { coefficient }\end{array}$ & $P$ & $\begin{array}{c}\text { \% variation } \\
\text { accounted }\end{array}$ & $\begin{array}{c}\text { S.E. of ob- } \\
\text { servation }\end{array}$ \\
\hline OPA2-25 & 86.2 & 0.019 & 26.7 & 57.7 \\
OPA3-59 & 69.9 & 0.047 & 18.6 & 60.8 \\
OPA4-101 & 121.1 & 0.002 & 45.6 & 51.3 \\
\hline
\end{tabular}


States, eastern England and Australia was reported by Shaw and Roth (1976), Rishbeth (1978) and Kile (1983). In Australia the majority (up to $71 \%$ ) of infection centres studied were occupied by single genets (Kile 1983).

'Clonal' reproduction via rhizomorphs or airborne asexual propagules occurs in A. ostoyae in west-central Poland. This is supported by the occurrence of identical genets. The population structure of $A$. ostoyae here was, however, more consistent with a sexual reproductive strategy, i.e. successive infections by basidiospores transferred from outside sources. Several earlier studies have produced indirect evidence of dispersal and infection via basidiospores (Rishbeth 1978, 1985, 1988; Kile 1983; Smith et al. 1994; Worrall 1994). Up to now, however, this has been considered rare in nature. The results of Stenlid and Gustafsson (2001) and Power et al. (2008) confirm, however, that dispersal and infection via basidiospores is possible in indigenous and non-indigenous forests. Many Armillaria basidiospores are released, thus providing potential inoculum for spread to other plantations and establishment of new infection centres. Given the enormous number of basidiospores produced by Armillaria fruiting bodies, it is probable that some will travel over large distances (Stenlid and Gustafsson 2001). The small proportion of spores dispersed over longer distances is crucial for the establishment of the pathogen in distant localities and for achieving genetic exchange between populations. According to Hood et al. (2002, 2008), A. novae-zelandiae is capable of colonizing freshly cut wood of $P$. radiata by means of basidiospores, and establishment of the pathogen in pine debris produced during site preparation may result in new infection centres in succeeding rotations. Knowledge of pathogen spread may help to predict the presence and extent of establishment of $A$. ostoyae in new stands.

The high genetic similarity (similarity coefficient values $>0.9$ ) found between isolate R1 from Zielonka I and R16 and R25 from Złotów II located more than $200 \mathrm{~km}$ away could be the result of successive, long-distance transfers of asexual propagules by a vector. Spread via rhizomorphs can be discounted because of the distance. The typical size of an infection centre occupied by a single genet of $A$. ostoyae ranges from 6.01- (0.01-0.44) -15.83 ha (Shaw and Roth 1976; Van der Kamp 1993; Worrall 1994; Legrand et al. 1996; Peet et al. 1996; Dettman and van der Kamp 2001; Ferguson et al. 2003).

The possibility of the development of new genets from inbreeding, genetic recombination or somatic mutation can not be discounted. The likelihood of somatic mutation is greater in genets advanced in size and age. A large-scale mutation such as a chromosomal rearrangement or segment deletion may produce additional RAPD markers. The high degree of polymorphism in A. ostoyae DNA may have resulted partly from a long-lasting and permanent host effect, resulting from a genetically diverse population of spruce and other admixture species in the previous forest. Spruce (Picea), its major host group, survived in Europe in several separate refuges, resulting from events mediated by the last Ice Ages (Silvertown 1987). Local isolation led to its genetic diversity, which could be transferred to its pathogens. The type of forest grown previously in the sample areas was fresh broadleaved forest or fresh mixed broadleaved forest. Apart from spruce, both had admixture of oak (Quercus), larch (Larix), hornbeam (Carpinus) and wild black cherry (Prunus). Previous exposure to alternative hosts, which generally causes relaxation or shifts in selection pressure, could contribute to greater genetic diversity (Burdon 1993; Burdon and Silk 1997).

The present study suggests that sexual reproduction in A. ostoyae (via basidiospores) may occur in Poland more often than was so far suspected. Such reproduction results in populations of larger numbers of relatively small fungal individuals (Dettman and van der Kamp 2001).

We found the genetic association between gene, phenotype and function of $A$. ostoyae. The molecular genetic basis of adaptive variation is of fundamental importance for evolutionary dynamics, but is still poorly known. Only in very few cases has the relationship between genetic variation at the molecular level, phenotype and function been established in natural populations (Kivimäki et al. 2007).

\section{Acknowledgements}

This work was supported by the research project from the Polish Ministry of Science and Higher Education (N303 077 31/2642).

\section{References}

Anonymous 2012. Krótkoterminowa prognoza występowania ważniejszych szkodników i chorób infekcyjnych drzew leśnych w Polsce w 2013 roku. Instytut Badawczy Leśnictwa, Sękocin Stary.

Baumgartner K., Rizzo D.M. 2001. Ecology of Armillaria spp. in a mixed-hardwood forests of California. Plant Disease 85: 947-951. http://dx.doi. org/10.1094/PDIS.2001.85.9.947

Baumgartner K., Coetzee M.P.A., Hoffmeister D. 2011. Secrets of the subterranean pathosystem of Armillaria. Molecular Plant Pathology 12: 515-534. http://dx.doi.org/10.1111/j.13643703.2010.00693.x

Bendel M. 2006. The spread of root rot fungi in mountain pine stands in the Swiss National Park: 
A case study of its influence on forest dynamics. PhD Diss., Swiss Federal Institute of Technology, Zurich, pp. 1-103.

Bolton R.G., Boddy L. 1993. Characterization of the spatial aspects of foraging mycelial cord systems using fractal geometry. Mycological Research 97: 762-768. http://dx.doi.org/10.1016/S09537562(09) 80158-5

Brazee N.J., Marra R.E., Wick R.L. 2012. Genotypic diversity of Armillaria gallica from mixed oak forests in Massachusetts. Mycologia 104: 53-61. http://dx.doi.org/10.3852/11-113

Burdon J.J. 1993. The structure of pathogen populations in natural plant communities. Annual Review of Phytopathology 31: 305-328. http://dx. doi.org/10.1146/annurev.py.31.090193.001513

Burdon J.J., Silk J. 1997. Sources and patterns of diversity in plant-pathogenic fungi. Phytopathology 87: 664-669. http://dx.doi.org/10.1094/PHYTO.1997.87.7.664

Cairney J.W.G., Jennings D.H., Ratcliffe R.G., Southon T.E. 1988. The physiology of basidiomycete linear organs. II. Phosphate uptake by rhizomorphs of Armillaria mellea. New Phytologist 109: 327-333. http://dx.doi.org/10.1111/j.1469-8137.1988. tb04202.x

Camussi A., Ottaviano E., Caliński T., Kaczmarek Z. 1985. Genetic distances based on quantitative traits. Genetics 111: 945-962.

Dettman J.R. 1999. The population structure of Armillaria ostoyae in the central and southern interior of British Columbia. MaS Thesis. British Columbia University.

Dettman J.R., van der Kamp B.J. 2001. The population structure of Armillaria ostoyae and Armillaria sinapina in the central interior of British Columbia. Canadian Journal of Botany 79: 600-611.

Ferguson B.A., Dreisbach T.A., Parks C.G., Filip G.M., Schmitt C.L. 2003. Coarse-scale population structure of pathogenic Armillaria species in a mixed-conifer forest in the Blue Mountains of northeast Oregon. Canadian Journal of Forest Research 33: 612-623. http://dx.doi.org/10.1139/ x03-065

Granlund H.I., Jennings D.H., Veltkamp K. 1984. Scanning electron microscope studies of rhizomorphs of Armillaria mellea. Nova Hedwigia 39: $85-100$.

Gregory S.C., Rishbeth J., Shaw C.G.III. 1991. Pathogenicity and virulence. In: Armillaria Root Disease. Agriculture Handbook No. 691. Shaw C.G. III, Kile G.A. (eds.). United States Department of Agriculture, Forest Service, Washington, pp. 76-87.

Guillaumin J.J., Mohammed C., Anselmi N., Courtecuisse R., Gregory S.C., Holdenrieder O., Intini M., Lung B., Marxmüller H., Morrison D., Rish- beth J., Termorshuizen A.J., Tirro A., Vandam B. 1993. Geographical distribution and ecology of the Armillaria species in Western Europe. European Journal of Forest Pathology 23: 321-341. http://dx.doi.org/10.1111/j.1439-0329.1993. tb00814.x

Guillaumin J.J., Anderson J.B., Legrand P., Ghahari S., Bertheley S. 1996. A comparison of different methods for the identification of genets of Armillaria spp. New Phytologist 133: 333-343. http:// dx.doi.org/10.1111/j.1469-8137.1996.tb01900.x

Hastie T.J., Tibshirani R.J. 1990. Generalized Additive Models. Chapman and Hall, London.

Hood I.A., Horner I.J., Gardner J.F., Sandberg C.J. 2002. Armillaria root disease of Pinus radiata in New Zealand. Basidiospore dispersal. New Zealand Journal of Forestry Science 32: 94-102.

Hood I.A., Petrini L.E., Gardner J.F. 2008. Colonisation of woody material in Pinus radiata plantations by Armillaria novae-zelandiae basidiospores. Australasian Plant Pathology 37: 347-352. http:// dx.doi.org/10.1071/AP08030

Kile G.A. 1983. Identification of genotypes and the clonal development of Armillaria luteobubalina Watling \& Kile in eucalypt forests. Australian Journal of Botany 31: 657-671. http://dx.doi. org/10.1071/BT9830657

Kivimäki M., Kärkkäinen K., Gaudeul M., Ľre G., Ĺgren J. 2007. Gene, phenotype and function: GLABROUS1 and resistance to herbivory in natural populations of Arabidopsis lyrata. Molecular Ecology 16: 453-462. http://dx.doi.org/10.1111/ j.1365-294X.2007.03109.x

Korhonen K. 1978. Infertility and clonal size in the Armillariella mellea complex. Karstenia 18: 31-42.

Kozak M., Bocianowski J., Sawkojć S., Wnuk A. 2010. Call for more graphical elements in statistical teaching and consultancy. Biometrical Letters 47: 57-68.

Lamour A., Termorshuizen A.J., Volker D., Jeger M.J. 2007. Network formation by rhizomorphs of Armillaria lutea in natural soil: their description and ecological significance. FEMS Microbiology Ecology 62: 222-232. http://dx.doi.org/10.1111/ j.1574-6941.2007.00358.x

Leake J., Johnson D., Donnelly D., Muckle G., Boddy L., Read D. 2004. Networks of power and influence: the role of mycorrhizal mycelium in controlling plant communities and agroecosystem functioning. Canadian Journal of Botany 82: 1016-1045. http://dx.doi.org/10.1139/b04-060

Legrand P., Guillaumin J.J. 1993. Armillaria species in the forest ecosystems of the Auvergne (Central France). Acta Oecologica 14: 389-403.

Legrand P., Ghahari S., Guillaumin J.J. 1996. Occurrence of genets of Armillaria spp. in four mountain forests in Central France: the col- 
onization strategy of Armillaria ostoyae. New Phytologist 133: 321-332. http://dx.doi. org/10.1111/j.1469-8137.1996.tb01899.x

Łakomy P. 1998. Monitoring huby korzeni i opieńkowej zgnilizny korzeni wybranych uprawach sosnowych krainy Wielkopolsko-Pomorskiej. Roczniki AR Poznań, Rozprawy Naukowe 283: 1-81.

Mahalanobis P.C. 1936. On the generalized distance in statistics. Proceedings of the Indian National Science Academy 12: 49-55.

Mihail J.D., Bruhn J.N. 2005. Foraging behaviour of Armillaria rhizomorph systems. Mycological Research 109: 1195-1207. http://dx.doi. org/10.1017/S0953756205003606

Morrison D.J. 1974. Effect of soil pH on rhizomorph growth of Armillaria mellea. Bi-monthly Research Notes 30: 18-19.

Morrison D.J. 1976. Vertical distribution of Armillaria mellea rhizomorphs in soil. Transactions of the British Mycological Society 66: 393-399. http:// dx.doi.org/10.1016/S0007-1536(76)80207-0

Morrison D.J. 1989. Pathogenicity of Armillaria species is related to rhizomorph growth habit. In: Proceedings 7th Int. Conf. Root and Butt Rots, Victoria and Vernon, British Columbia, Canada. August, 9-16, 1988. Morrison D.J. (ed.). Victoria, Canada, pp. 584-589.

Morrison D.J. 2004. Rhizomorph growth habit, saprophytic ability and virulence of 15 Armillaria species. Forest Pathology 34: 15-26. http://dx.doi. org/10.1046/j.1439-0329.2003.00345.x

Nei M., Li W.H. 1979. Mathematical model for studying genetic variation in terms of restriction endonucleases. Proceedings of the National Academy of Sciences of the United States of America 76: 5269-5273. http://dx.doi.org/10.1073/ pnas.76.10.5269

Pareek M., Cole L., Ashford A.E. 2001. Variations in structure of aerial and submerged rhizomorphs of Armillaria luteobubalina indicate that they may be organs of absorption. Mycological Research 105: 1377-1387. http://dx.doi.org/10.1017/ S0953756201004622

Pareek M., Allaway W.G., Ashford A.E. 2006. Armillaria luteobubalina mycelium develops air pores that conduct oxygen to rhizomorph clusters. Mycological Research 110: 38-50. http://dx.doi. org/10.1016/j.mycres.2005.09.006

Pearce M.H., Malajczuk N. 1990. Factors affecting the growth of Armillaria luteobubalina rhizomorphs in soil. Mycological Research 94: 38-48. http:// dx.doi.org/10.1016/S0953-7562(09)81262-8

Peet F.G., Morrison D.J., Pellow K.W. 1996. Rate of spread of Armillaria ostoyae in two Douglas-fir plantations in the southern interior of British Co- lumbia. Canadian Journal of Forest Research 26: 148-151. http://dx.doi.org/10.1139/x26-016

Power M.W.P., Ramsfield T.D., Hood I.A. 2008. Detection of Armillaria basidiospore dispersal. New Zealand Plant Protection 61: 35-40.

Prospero S., Rigling D., Holdenrieder O. 2003. Population structure of Armillaria species in managed Norway spruce stands in the Alps. New Phytologist 158: 365-373. http://dx.doi.org/10.1046/ j.1469-8137.2003.00731.x

Prospero S., Holdenrieder O., Rigling D. 2004. Comparison of the virulence of Armillaria cepistipes and Armillaria ostoyae on four Norway spruce provenances. Forest Pathology 34: 1-14. http://dx.doi. org/10.1046/j.1437-4781.2003.00339.x

Prospero S., Holdenrieder O., Rigling D. 2006. Rhizomorph production and stump colonization by co-occurring Armillaria cepistipes and Armillaria ostoyae: an experimental study. Forest Pathology 36: 21-31. http://dx.doi.org/10.1111/j.14390329.2006.00426.x

Redfern D.B. 1973. Growth and behaviour of Armillaria mellea rhizomorphs in soil. Transactions of the British Mycological Society 61: 569-581. http:// dx.doi.org/10.1016/S0007-1536(73)80126-3

Redfern D.B. 1978. Infection by Armillaria mellea and some factors affecting host resistance and the severity of disease. Forestry 51: 121-135. http:// dx.doi.org/10.1093/forestry/51.2.121

Redfern D.B., Filip G.M. 1991. Inoculum and infection. In: Armillaria Root Disease. Agricultural Handbook No. 691. Shaw C.G. III, Kile G.A. (eds.). United States Department of Agriculture, Forest Service, Washington, pp. 448-461.

Rishbeth J. 1978. Infection foci of Armillaria mellea in first-rotation hardwoods. Annals of Botany 42: 1131-1139.

Rishbeth J. 1982. Species of Armillaria in southern England. Plant Pathology 31: 9-17. http://dx.doi. org/10.1111/j.1365-3059.1982.tb02806.x

Rishbeth J. 1984. Pathogenicity test for Armillaria. In: Proceedings $6^{\text {th }}$ Int. Conf. Root and Butt Rots of Forest Trees. August, 25-31, 1983, Kile G.A. (ed.). Victoria and Gympie, Australia, pp. 131-139.

Rishbeth J. 1985. Infection cycle of Armillaria and host response. European Journal of Forest Pathology 15: 332-341. http://dx.doi. org/10.1111/j.1439-0329.1985.tb01108.x

Rishbeth J. 1988. Stump infection by Armillaria in first-rotation conifers. European Journal of Forest Pathology 18: 401-408. http://dx.doi. org/10.1111/j.1439-0329.1988.tb00229.x

Rizzo D.M., Harrington T.C. 1993. Delineation and biology of clones of Armillaria ostoyae, A. gemina and A. calvescens. Mycologia 85: 164-174. http:// dx.doi.org/10.2307/3760452 
Seidler-Łożykowska K., Bocianowski J. 2012. Evaluation of variability of morphological traits of selected caraway (Carum carvi L.) genotypes. Industrial Crops and Products 35: 140-145. http://dx.doi. org/10.1016/j.indcrop.2011.06.026

Shaw C.G. III., Roth L.F. 1976. Persistence and distribution of a clone of Armillaria mellea in a ponderosa pine forest. Phytopathology 66: 1210-1213. http://dx.doi.org/10.1094/Phyto-66-1210

Schulze S., Bahnweg G., Möller E.M. Sandermann H. 1997. Identification of the genus Armillaria by specific amplification of an rDNA-ITS fragment and evaluation of genetic variation within $A$. ostoyae by rDNA-RFLP and RAPD analysis. European Journal of Forest Pathology 27: 225-239. http:// dx.doi.org/10.1111/j.1439-0329.1997.tb00865.x

Silvertown J. 1987. Plant Population Ecology. Longman, London.

Singh P. 1981. Some observations on the behaviour of Armillaria mellea and the damage caused to Scots pine in Newfoundland. In: Root and Butt rots in Scots Pine Stands.PAN, Poznań, Poland, pp. 78-91.

Smith M.L., Bruhn J.N., Anderson J.B. 1992. The fungus Armillaria bulbosa is among the largest and oldest living organisms. Nature 356: 428-431. http://dx.doi.org/10.1038/356428a0

Smith M.L., Bruhn J.N., Anderson J.B. 1994. Relatedness and spatial distribution of Armillaria genets infecting red pine seedlings. Phytopathology 84: 822-829. http://dx.doi.org/10.1094/ Phyto-84-822
Stenlid J., Gustafsson M. 2001. Are rare wood decay fungi threatened by inability to spread? Ecological Bulletins 49: 85-91.

Thompson W., Rayner A.D.M. 1983. Extent, development and function of mycelial cord systems in soil. Transactions of the British Mycological Society 81: 333-345. http://dx.doi.org/10.1016/ S0007-1536(83)80085-0

Van der Kamp B.J. 1993. Rate of spread of Armillaria ostoyae in the central interior of British Columbia. Canadian Journal of Forest Research 23: 12391241. http://dx.doi.org/10.1139/x93-156

Watkinson S.C., Boddy L., Burton K., Darrah P.R., Eastwood D., Fricker M.D., Tlalka M. 2005. New approaches to investigating the function of mycelial networks. Mycologist 19: 11-17. http://dx. doi.org/10.1017/S0269915X05001023

Weinhold A.R. 1963. Rhizomorph production by Armillaria mellea induced by ethanol and related compounds. Science 142: 1065-1066. http://dx. doi.org/10.1126/science.142.3595.1065

Williams J.G.K., Kubelik A.R., Livak K.J., Rafalski J.A., Tingey S.V. 1990. DNA polymorphisms amplified by arbitrary primers are useful as genetic markers. Nucleic Acids Research 18: 6531-6535. http://dx.doi.org/10.1093/nar/18.22.6531

Worral J.J. 1994. Population structure of Armillaria species in several forest types. Mycologia 86: 401407. http://dx.doi.org/10.2307/3760572

Żółciak A. 2007. Armillaria species in coniferous stands. Acta Mycologica 42: 211-217. http://dx. doi.org/10.5586/am.2007.024 